STUDIA Z PRAWA WYZNANIOWEGO

Tom $24-2021$

DOI: https://doi.org/10.31743/spw.12692

LIDIA K. JASKUŁA*

\title{
WOLNOŚĆ SŁOWA REALIZOWANA W RAMACH WOLNOŚCI RELIGII W KOŚCIELE KATOLICKIM W POLSCE A PRAWNE OGRANICZENIA DOTYCZĄCE EPIDEMII SARS-COV-2
}

Freedom of speech exercised within freedom of religion in the Catholic Church in Poland and the legal restrictions concerning the SARS-CoV-2 epidemic

Streszczenie: Niniejszy artykuł stanowi próbę analizy stanu wolności słowa realizowanej w ramach praktyk religijnych wykonywanych publicznie w czasie epidemii. Główny problem opracowania stanowi pytanie, czy ograniczenia wprowadzane w wyniku epidemii SARS-CoV-2 wpływają na wolność słowa realizowaną $\mathrm{W}$ ramach wolności religii. $\mathrm{W}$ artykule omówiono normatywne ramy wolności słowa realizowanej w ramach wolności religii, ograniczenia dotyczące funkcjonowania Kościoła Katolickiego, które wprowadzono w Polsce w ramach walki z epidemią SARS-CoV-2 oraz praktyczne konsekwencje tych ograniczeń dla wolności słowa w analizowanym kontekście. Przeprowadzone badania doprowadziły do wniosku, że ograniczanie wolności religii w jej wymiarze zewnętrznym jest także ograniczaniem wolności słowa realizowanej $\mathrm{w}$ ramach wolności religii. Ustanowione w Polsce ograniczenia nie spełniają prawnych warunków ograniczania wolności człowieka. W obliczu zagrożeń związanych z epidemią SARS-CoV-2 ograniczanie niektórych praw i wolności w celu ochrony życia i zdrowia jest co do zasady uzasadnione, jednak działania takie powinny respektować wymogi prawa. Działania przeciwne prowadzą do erozji prawa, niszczą jego autorytet, naruszają prawa i wolności jednostki i negatywnie odbijają się na relacji państwo-Kościół. Takich „standardów” sprawowania administracji publicznej nie

* Dr, Katedra Prawa Administracyjnego, Wydział Prawa, Prawa Kanonicznego i Administracji, Katolicki Uniwersytet Lubelski Jana Pawła II, Al. Racławickie 14, 20-950 Lublin, e-mail: lilajas@kul.pl. ORCID 0000-0003-3619-5826. 
może usprawiedliwiać epidemia i nie jest możliwe ich zaakceptowanie w demokratycznym państwie prawa.

Słowa kluczowe: wolność słowa; wolność religii; epidemia; SARS-CoV-2; prawne ograniczenia

Abstract: The present paper is an attempt to analyze the state of freedom of speech exercised during public religious practices at the time of the epidemic. The main research problem addressed in the study is whether the restrictions introduced due to the SARS-CoV-2 epidemic affect freedom of speech exercised within freedom of religion. The paper discusses the normative framework of freedom of speech exercised within freedom of religion, the restrictions on the functioning of the Catholic Church established to control the SARS-CoV-2 epidemic in Poland, and the practical consequences of these restrictions for freedom of speech in the context under discussion. The conducted analyses have led to the conclusion that restricting freedom of religion in its external dimension also means restricting freedom of speech exercised within freedom of religion. The restrictions in place in Poland do not meet the legal conditions for limiting human freedom. Therefore, it should be emphasized that in the face of the threats posed by the SARS-CoV-2 epidemic, limitations of certain rights and freedoms introduced in order to protect life and health are essentially justified, but such actions should respect legal requirements. The opposite may lead to the erosion of the law, destroy its authority, violate the rights and freedoms of individuals, and negatively affect Church-State relations. Such "standards" of public administration cannot be justified by an epidemic and it is not possible to accept them in a democratic state ruled by law.

Key words: freedom of speech; freedom of religion; epidemic; SARS-CoV-2; legal restrictions

\section{WPROWADZENIE}

Wolność słowa i wolność religii są zasadami demokratycznego państwa prawa. Realizacja obu wolności w życiu społecznym doprowadza nierzadko do ich konfrontacji i konieczności ważenia, której z nich dać pierwszeństwo. Warto jednak pamiętać, że obie wolności mogą się wzajemnie uzupełniać i wzmacniać. Wolność słowa może być realizowana w ramach wolności religii, a wolność religii może być realizowana poprzez wolność słowa. Podejmując niniejszy temat, przestrzeń na zaistnienie i realizację wolności słowa w ramach wolności religii Autorka odnajduje w obszarze 
„uzewnętrzniania religii”. Realizacja tego wymiaru wolności religii zakłada korzystanie z wolności słowa. Te dwie wolności w tym obszarze są ze sobą ściśle powiązane.

Epidemia wirusa SARS-CoV-2 w Polsce spowodowała wprowadzanie w życie regulacji prawnych, które ograniczały część z gwarantowanych prawem wolności i praw człowieka. Te, które wpływały na funkcjonowanie Kościoła Katolickiego w Polsce budziły szczególne dyskusje. Podnoszono w nich argumenty zarówno o dyskryminowaniu, jak i o faworyzowaniu tej instytucji na tle innych podmiotów życia publicznego ${ }^{1}$. Nie zmienia to faktu, że ograniczenia dotyczące epidemii SARS-CoV-2 wpływające na funkcjonowanie Kościoła Katolickiego należy traktować jako ingerencję w wolność religii ${ }^{2}$. Ingerencje takie miały miejsce w wielu państwach, a źródło ich dolegliwości upatrywane jest w znaczeniu wolności religii ${ }^{3}$. W kontekście podjętego tematu opracowania rodzi to automatycznie pytanie o skutki wprowadzanych ograniczeń dla wolności słowa realizowanej w ramach wolności religii.

Główny problem niniejszego opracowania można sformułować w pytaniu: czy ograniczenia wprowadzane w wyniku epidemii SARS-CoV-2 w Polsce wpływają na wolność słowa realizowaną w ramach

1 Znaczenie Kościoła Katolickiego jako podmiotu życia społecznego wynika w Polsce już z samego faktu, że należy doń ponad $30 \mathrm{mln}$ Polaków (zob. Stanisz 2020, 15). Wszystko, co dotyczy tej instytucji, jest przedmiotem sporego zainteresowania publicznego. Argumenty o dyskryminowaniu, jak i o faworyzowaniu Kościoła w przepisach wprowadzanych w związku z epidemią pojawiały się w wypowiedziach osób publicznych. O dyskryminowaniu Kościoła w czasie pandemii mówił m.in. abp Stanisław Gądecki: „W sumie, należy stwierdzić, że mimo gwarancji konstytucyjnych i konkordatowych Kościół został potraktowany gorzej, niż przedsiębiorstwa handlowe; jako dziedzina niekonieczna do życia. Rządy z przeszłości nigdy nie ośmieliły się nałożyć na Kościół tak drastycznych zakazów, okazując w ten sposób znikomy respekt dla Kościoła i jego roli w życiu społecznym” (Gądecki 2021). Przykładem tezy o faworyzowaniu Kościoła jest natomiast wypowiedź Adama Szostkiewicza: „Owszem, mamy w Polsce wolność religijną, lecz mamy teraz także ofensywę zabójczego wirusa. W interesie publicznym leży jej zahamowanie i nie powinno tu być żadnych wyjątków, żadnego mrugania rządzących do władzy kościelnej, że jej więcej wolno. Pandemia jest ślepa na znaki religijne i barwy polityczne. Tak samo ślepa powinna być na nie władza świecka" (Szostkiewicz 2020).

2 Zagadnienie zgodności z prawem wprowadzanych ograniczeń zostanie podjęte w dalszej części artykułu.

3 Zob. del Castillo, Biana, Joaquin 2020, 633. 
wolności religii? Rozstrzygnięciu postawionego problemu służyć będzie postawienie pytań szczegółowych: jakie są normatywne ramy wolności słowa realizowanej w ramach wolności religii? jakie ograniczenia dotyczące funkcjonowania Kościoła Katolickiego wprowadzono w Polsce w ramach walki z epidemią SARS-CoV-2? A także, czy, a jeśli tak, to jakie praktyczne konsekwencje wynikają z wprowadzanych ograniczeń dla wolności słowa realizowanej $\mathrm{w}$ ramach wolności religii? Przeprowadzone analizy i odpowiedź na pytania szczegółowe pozwoli na rozstrzygnięcie problemu głównego.

\section{NORMATYWNE RAMY WOLNOŚCI SŁOWA REALIZOWANEJ W RAMACH WOLNOŚCI RELIGII}

Wskazanie normatywnych ram wolności słowa realizowanej w ramach wolności religii wymaga zakreślenia normatywnych ram jednej i drugiej. Obie wolności są gwarantowane w szeregu aktów prawnych rangi międzynarodowej i krajowej. W przepisach prawa międzynarodowego wolności religii w porządku prawnym ONZ dotyczy art. 18 Międzynarodowego Paktu Praw Obywatelskich i Politycznych ${ }^{4}$, w dokumentach Rady Europy - art. 9 Konwencji o Ochronie Praw Człowieka i Podstawowych Wolności ${ }^{5}$, a w przepisach Unii Europejskiej - art. 10 Karty Praw Podstawowych Unii Europejskiej ${ }^{6}$. W systemie prawa polskiego wolność religii jest też chroniona w Konstytucji $\mathrm{RP}^{7}$ i ustawach. Analogicznie rzecz ma się z wolnością słowa. Odnoszą się do niej: art. 19 MPPOiP, art. 10 EKPC, art. $11 \mathrm{KPP}$, przepisy polskiej Konstytucji i ustaw. Wszystkie przywołane akty zawierają klauzule, w których określono przesłanki wyjątkowej dopuszczalności ograniczeń obu wolności.

4 Międzynarodowy Pakt Praw Obywatelskich i Politycznych, Dz. U. z 1977 r. Nr 38, poz. 167, dalej: MPPOiP.

5 Konwencja o Ochronie Praw Człowieka i Podstawowych Wolności, Dz. U. z 1993 r. Nr 61, poz. 284, dalej: EKPC.

6 Karta Praw Podstawowych Unii Europejskiej, Dz. Urz. UE C 326 z 26.10.2012 r., s. 391, dalej: KPP.

7 Konstytucja Rzeczypospolitej Polskiej z dnia 2 kwietnia 1997 r., Dz. U. z 1997 r., $\mathrm{Nr} 78$, poz. 483 z późn. zm. 
Analiza wskazanych przepisów Konwencji, Paktu oraz Karty odnoszących się do wolności religii prowadzi do wniosku, że przyjęta w każdym z nich konstrukcja normatywna, w tym treść i poziom ochrony wolności religii (wyznania) są bardzo podobne. W Europie zasadnicze znaczenie dla ochrony wolności religii ma EKPC. Zgodnie z jej art. 9 każdy ma prawo do wolności myśli, sumienia i wyznania ${ }^{8}$. Prawo to obejmuje wolność zmiany wyznania lub przekonań oraz wolność uzewnętrzniania indywidualnie lub wspólnie z innymi, publicznie lub prywatnie, swego wyznania lub przekonań przez uprawianie kultu, nauczanie, praktykowanie i czynności rytualne. Wolność ta może podlegać ograniczeniom tylko w jednym jej aspekcie - w aspekcie uzewnętrzniania wyznania (religii) lub przekonań9. Ewentualne ograniczenia muszą być przewidziane przez prawo ${ }^{10}$ i konieczne w społeczeństwie demokratycznym z uwagi na interesy bezpieczeństwa publicznego, ochronę porządku publicznego, zdrowia i moralności lub ochronę praw i wolności innych osób. Ograniczenia powinny zatem przejść pozytywnie test trzech kryteriów: legalności, konieczności

8 Szczegółowo o zakresie i treści wolności religii w EKPC piszą m.in.: Sobczak 2008, 87-116; Falski 2015, 77-90; Wółkowska 2013, 241-260.

9 W literaturze przedmiotu podkreśla się, że wolność religijna należy przede wszystkim do sfery świadomości ludzkiej, ale konkretyzuje się i realizuje w sferze zewnętrznej. Sposoby uzewnętrzniania religii mogą być różnorakie, a ich pełne przedstawienie jest niemożliwe i niewskazane. Uzewnętrznianie przekonań religijnych najczęściej dokonuje się przez nauczanie i wykonywanie praktyk religijnych (zob. Mezglewski, Misztal, Stanisz 2008, 87-91).

10 Tłumaczenie oficjalne, opublikowane w Dzienniku Ustaw, zawiera sformułowanie „przewidziane przez ustawę”. Jednak, jak podkreśla I. C. Kamiński, sformułowanie to należy rozumieć jako ingerencję przewidzianą przez prawo - wcześniej istniejące i znane prawo krajowe, a przekonuje do tego praktyka orzecznicza ETPC, bowiem jako prawo krajowe są traktowane nie tylko reguły tworzone przez państwowe instytucje prawotwórcze, ale również np. organy samorządu zawodowego, jeśli wydawane przez nie przepisy powstały na mocy delegacji prawotwórczej. Autor ten przypomina również, że prawem krajowym jest też ratyfikowane prawo międzynarodowe, jeśli staje się podstawą prawną dla ingerencji dokonywanej przez instytucje państwa i również ono musi spełniać identyczne nakazy przewidywalności jak te, które są łączone z „czystym” prawem krajowym (zob. Kamiński 2010, 27). Warto dodać, że od lat przedstawiciele doktryny podkreślają, iż tłumaczenie to zawiera błędy (zob. Gardocki 1993, 11; Kamiński 2002, 12; Kamiński 2008, 35; Kamiński 2010, 27; Nowicki 2017, 743; Nowińska 2007, 20-21). 
oraz celowości ${ }^{11}$. Zagadnienie to rozwija I. C. Kamiński podkreślając, że art. 9 EKPC zezwala zatem na dokonywanie ograniczeń tylko w obszarze identyfikowanym jako tzw. forum externum, przypominając, że istnieje tym samym również „sfera wewnętrzna”, forum internum, związana z posiadaniem poglądów oraz ich modyfikacją (obejmującą także ich porzucenie), która musi pozostać wolna od jakiejkolwiek ingerencji, a każde ograniczenie „wolności wewnętrznej” jest ex definitione sprzeczne z EKPC ${ }^{12}$. Jak łatwo zauważyć, Konwencja chroni wolność religii (wyznania) w sposób szeroki: w wymiarze wewnętrznym w sposób absolutny, w wymiarze zewnętrznym w sposób dopuszczający ograniczenia tylko w wyjątkowych sytuacjach.

Wolność sumienia i religii jest zapewniona każdemu przez Konstytucję RP (art. 53), zgodnie z którą wolność religii obejmuje z jednej strony wolność wyznawania lub przyjmowania religii według własnego wyboru, a z drugiej wolność uzewnętrzniania swojej religii, a to może następować przez uprawianie kultu, modlitwę, uczestniczenie w obrzędach, praktykowanie i nauczanie. Zatem także w regulacji krajowej najwyższej rangi ustrojodawca rozróżnia forum internum i forum externum i postanawia, że tylko wolność uzewnętrzniania religii może podlegać ograniczeniom. Ograniczenia mogą być wprowadzone wyłącznie w drodze ustawy i tylko wtedy, gdy jest to konieczne dla ochrony wartości wskazanych w art. 53 ust. 5 Konstytucji RP (bezpieczeństwo państwa, porządek publiczny, zdrowie, moralność lub wolność i prawa innych osób). Z przepisami konstytucyjnymi zasadniczo korespondują przepisy ustawy z dnia 17 maja 1989 r. o gwarancjach wolności sumienia i wyznania ${ }^{13}$, choć w tym przypadku Rzeczpospolita Polska pierwszorzędnie zapewnia wolność sumienia i wyznania obywatelom i dopiero następnie zrównuje z nimi cudzoziemców i bezpaństwowców (art. 1 ust. 1 oraz art. 7). W ujęciu cytowanej ustawy wolność sumienia i wyznania obejmuje swobodę wyboru religii lub przekonań oraz wyrażania ich indywidualnie i zbiorowo, prywatnie i publicznie (art. 1 ust. 2). Natomiast uzewnętrznianie religii może

11 Wiśniewski 2013, 261.

12 Kamiński 2012, 220.

13 Ustawa z dnia 17 maja 1989 r. o gwarancjach wolności sumienia i wyznania, tekst jedn. Dz. U. z 2017 r., poz. 1153, dalej: u.g.w.s. 
podlegać jedynie koniecznym ograniczeniom ustawowym, na zasadach wskazanych w ustawie (art. 3 ust. 1).

Z normatywnym modelem wolności religii należy zestawić normatywny model wolności słowa. Zabieg ten pozwoli nam ustalić relację, w jakiej pozostają te wolności w stosunku do siebie. Podobnie jak wolność religii, także wolność słowa jest regulowana zarówno w aktach międzynarodowych, jak i krajowych, a jej realizacja może podlegać ograniczeniom.

Analiza postanowień MPPOiP, EKPC i KPP prowadzi do wniosku, że przyjęto w nich bardzo zbliżony model normatywny i standard ochrony wolności słowa. W Konwencji wolność słowa jest zagwarantowana w formie wolności wyrażania opinii (art. 10). W art. 10 ust. 2 EKPC prawnie usankcjonowano nierozerwalność wolności z obowiązkami oraz odpowiedzialnością. Postanowiono, iż korzystanie z wolności słowa może podlegać wymogom formalnym, warunkom, ograniczeniom i sankcjom, które są przewidziane przez prawo i są konieczne w społeczeństwie demokratycznym dla ochrony wskazanych w Konwencji wartości, a więc: bezpieczeństwa państwowego, integralności terytorialnej i bezpieczeństwa publicznego, ze względu na konieczność zapobieżenia zakłóceniu porządku lub przestępstwu, ochrony zdrowia lub moralności, ochrony dobrego imienia i praw innych osób, w celu zapobieżenia ujawnieniu informacji poufnych bądź zagwarantowania powagi i bezstronności władzy sądowej. Także w przypadku wolności słowa każde jej ograniczenie jest poddawane trójelementowemu testowi przy użyciu kryteriów legalności, celowości i niezbędności ${ }^{14}$.

W prawie krajowym również w odniesieniu do wolności słowa punktem wyjścia są przepisy Konstytucji RP. Model przyjęty w przepisach ustawy zasadniczej stanowi podstawę dla rozwiązań szczegółowych przyjmowanych w ustawach i aktach niższego rzędu.

Konstytucja RP zagadnieniu wolności słowa poświęca art. 54 ust. 1, zgodnie z którym „każdemu zapewnia się wolność wyrażania swoich poglądów oraz pozyskiwania i rozpowszechniania informacji”. Przepis ten gwarantuje wolność przekonań, koncentrując się na wolności ich wyrażania, a więc ich uzewnętrzniania, wprowadzania do obiegu publicznego. Z wolnością wyrażania poglądów prawodawca wiąże dwa kolejne

14 Szczegółowo na ten temat: Kamiński 2010, 43. 
obszary chronione: wolność pozyskiwania informacji i wolność ich rozpowszechniania. Są one ze sobą immanentnie związane. Tak rozumiana wolność słowa urzeczywistnia się w trakcie korzystania z wolności religii. Pisząc o treści i zakresie wolności słowa należy pamiętać, że w jej przestrzeni mieści się także wolność prasy, co w przypadku tematu niniejszego opracowania ma znaczenie w odniesieniu do prasy katolickiej. Wolność słowa warunkuje istnienie prasy, a prasa w ramach swojej działalności korzysta i realizuje wolność słowa ${ }^{15}$. J. Sobczak podkreśla, że gwarantem wolności prasy jest państwo ${ }^{16}$. Owo „bycie gwarantem” nie oznacza opisu stanu faktycznego, ale określa konkretne obowiązki i zadania państwa. Podmiotom działającym w ramach wolności prasy przysługują także pozostałe składowe wolności słowa (omówione już w związ$\mathrm{ku} \mathrm{z}$ art. 54 Konstytucji RP), a ponadto również uprawnienia wskazane w art. 61 Konstytucji RP.

Świadomość, że prawa i wolności konstytucyjne nie mogą mieć absolutnego charakteru zawsze towarzyszyła wszystkim demokratycznym społeczeństwom, choć różne były formy jej wyrażania w tekstach ustaw zasadniczych ${ }^{17}$. Zatem również wolność wypowiedzi nie ma charakteru absolutnego. Zgodnie z art. 31 ust. 3 Konstytucji RP ograniczenia, o których mowa, mogą być ustanawiane tylko w ustawie i tylko wtedy, gdy są konieczne w demokratycznym państwie (tzw. przesłanka proporcjonalności),

15 Zgodnie z art. 14 Konstytucji RP, „Rzeczpospolita Polska zapewnia wolność prasy i innych środków społecznego przekazu”. Warto zauważyć, że desygnat pojęcia prasy w Konstytucji RP nie jest tożsamy z desygnatem tego samego pojęcia, wyznaczonym przez jego legalną definicję z art. 7 ust. 2 pkt 1 ustawy z dnia 24 stycznia 1984 r. - Prawo prasowe (Dz. U. z 2018 r., poz. 1914, dalej: pr. pras.). Ustrojodawca choć nie był związany definicją prasy przyjętą w ustawie, swoimi decyzjami doprowadził do chaosu pojęciowego. Konstytucyjny desygnat pojęcia prasy jest węższy niż desygnat ustawowy. Analiza treści art. 14 i art. 54 ust. 2 Konstytucji RP może prowadzić do wniosku, że w chwili wejścia w życie Konstytucji ,prasa” w ujęciu konstytucyjnym oznaczała tylko drukowane publikacje periodyczne (tak: Jaskuła 2008, 40-41). Wraz z rozwojem nowych technologii, w których publikacje periodyczne są objęte szeroką, ustawową definicją ,,prasy”, przez ,prasę” w ujęciu konstytucyjnym można rozumieć wszystkie publikacje periodyczne, z wyłączeniem tych, które są rozpowszechniane za pomocą radiofonii i telewizji. Na temat chaosu pojęciowego: Nowińska 2007, 34-37; Sobczak 2008, 62-63, 313.

16 Zob. Sobczak 2000, 162.

17 Garlicki 2001, 5. 
dla jego bezpieczeństwa lub porządku publicznego, dla ochrony środowiska, zdrowia i moralności publicznej oraz wolności i praw innych osób. Jednocześnie ograniczenia te nie mogą naruszać „istoty wolności i praw"18, przy czym doktryna łączy koncepcję ,istoty” przede wszystkim z zakazem ustanawiania ograniczeń, które przekreślają tożsamość danego prawa bądź wolności, albo powodują ich wydrążenie z rzeczywistej treści $^{19}$. Jest to typowa klauzula generalna, która nieustannie wymaga redefiniowania, stosownie do zmiennego kontekstu społecznego ${ }^{20}$.

Zakreślając normatywne ramy wolności słowa realizowanej w ramach wolności religii, należy przede wszystkim zaznaczyć, że może się to dokonywać wyłącznie $\mathrm{w}$ aktach uzewnętrzniania religii, a więc $\mathrm{w}$ takich formach i w takim zakresie, w jakim uzewnętrznianie religii może mieć miejsce. $\mathrm{W}$ związku $\mathrm{z}$ tym wolność słowa realizowana $\mathrm{w}$ ramach wolności religii będzie podlegać tym ograniczeniom, którym podlega uzewnętrznianie wolności religii. Warto jednak postawić pytanie, na ile te ograniczenia modyfikują podstawowe ramy normatywne wolności słowa, rozpatrywanej jako wolność samoistna. Zestawienie ograniczeń, którym podlega uzewnętrznianie religii z ograniczeniami, którym podlega wolność słowa prowadzi do wniosku, że ta druga może być limitowana w większym zakresie niż wolność uzewnętrzniania religii. Na gruncie Konstytucji RP pierwsza z wymienionych wolności może być ograniczana z uwagi na bezpieczeństwo lub porządek publiczny, ochronę środowiska, zdrowia i moralności publicznej oraz wolności i praw innych osób, a druga z uwagi na bezpieczeństwo państwa, porządek publiczny, zdrowie, moralność lub wolność i prawa innych osób. Wynika to z natury i specyfiki obu wolności, które mają swoje odzwierciedlenie w przepisach prawa. Zatem we wszystkich tych sytuacjach, w których dopuszczone jest zgodne z prawem ograniczanie wolności religii, dopuszczone jest też ograniczanie wolności słowa. Konsekwentnie we wszystkich tych sytuacjach, w których dochodzi do ograniczania wolności religii w aktach

18 Warto pamiętać, że niektóre ograniczenia wprowadzane ze względu na rozwój epidemii koronawirusa naruszały istotę odnośnych wolności - np. całkowity zakaz zgromadzeń (tak: Florczak-Wątor 2020, 16).

19 Garlicki 2001, 22.

20 Por. Garlicki, Wojtyczek 2016, Art. 31. 
uzewnętrzniania religii, może dochodzić do faktycznego ograniczania wolności słowa.

\section{OGRANICZENIA DOTYCZĄCE FUNKCJONOWANIA KOŚCIOŁA KATOLICKIEGO W RAMACH WALKI Z EPIDEMIĄ SARS-COV-2}

Ograniczenia wprowadzane w ramach walki z epidemią SARS-CoV-2 dotyczyły zarówno jednostek, jak i instytucji, w tym Kościoła Katolickiego. Każde ich ogłoszenie było źródłem dyskusji na temat ich legalności i zasadności.

Gdy potwierdzono obecność wirusa SARS-CoV-2 w Polsce, na terenie naszego państwa ogłoszono, na podstawie ustawy z dnia 5 grudnia 2008 r. ${ }^{21}$, kolejno: w pierwszym etapie stan zagrożenia epidemicznego ${ }^{22}$, a następnie stan epidemii ${ }^{23}$. Sprawujący administrację rządową w państwie konsekwentnie stali na stanowisku, że istniejąca w kraju

21 Ustawa z dnia 5 grudnia 2008 r. o zapobieganiu oraz zwalczaniu zakażeń i chorób zakaźnych u ludzi, Dz. U. z 2020 r., poz. 1845, dalej: u.z.z.z.ch.z.

22 Ustawodawca stan zagrożenia epidemicznego definiuje jako „sytuację prawną wprowadzoną na danym obszarze w związku z ryzykiem wystąpienia epidemii w celu podjęcia określonych w ustawie działań zapobiegawczych", natomiast zagrożenie epidemiczne rozumie jako ,zaistnienie na danym obszarze warunków lub przesłanek wskazujących na ryzyko wystąpienia epidemii” (art. 2 pkt 23 i 31 u.z.z.z.ch.z.). Omawiany stan został wprowadzony na podstawie art. 46 ust. 2 i 4 u.z.z.z.ch.z. rozporządzeniem Ministra Zdrowia z dnia 13 marca 2020 r. w sprawie ogłoszenia na obszarze Rzeczypospolitej Polskiej stanu zagrożenia epidemicznego (Dz. U. z 2020 r., poz. 433), a uchylony 20 marca 2020 r., w związku z ogłoszeniem stanu epidemii.

23 Ustawodawca przez stan epidemii rozumie ,sytuację prawną wprowadzoną na danym obszarze $\mathrm{w}$ związku $\mathrm{z}$ wystąpieniem epidemii, $\mathrm{w}$ celu podjęcia określonych w ustawie działań przeciwepidemicznych i zapobiegawczych, dla zminimalizowania skutków epidemii”. Natomiast epidemia to „wystąpienie na danym obszarze zakażeń lub zachorowań na chorobę zakaźną w liczbie wyraźnie większej niż we wcześniejszym okresie albo wystąpienie zakażeń lub chorób zakaźnych dotychczas niewystępujących" (art. 2 pkt 22 i 9 u.z.z.z.ch.z.). Stan ten został wprowadzony na podstawie art. 46 ust. 2 i 4 u.z.z.z.ch.z. rozporządzeniem Ministra Zdrowia z dnia 20 marca 2020 r. w sprawie ogłoszenia na obszarze Rzeczypospolitej Polskiej stanu epidemii (Dz. U. z 2020 r., poz. 491 z późn. zm.). 
sytuacja sanitarna nie wymaga wprowadzenia któregokolwiek ze stanów nadzwyczajnych ${ }^{24}$.

W Polsce regulacje dotyczące funkcjonowania Kościoła Katolickiego (podobnie jak i innych związków wyznaniowych), związane z epidemią SARS-CoV-2, wyznaczały limit osób, które mogą być obecne fizycznie w miejscu sprawowania kultu lub obrzędów religijnych (najpierw wskazywano konkretną, dopuszczalną liczbę uczestników ceremonii, a następnie liczbę metrów kwadratowych, które muszą przypadać na jedną osobę) oraz sposób zachowania się uczestników takich zgromadzeń, nakładając obowiązek zachowania wskazanej odległości oraz noszenia maseczek. Na gospodarzy miejsca nakładano również obowiązki informowania o ograniczeniach i obowiązek zapewnienia ich przestrzegania. Pierwsze ograniczenia zostały wprowadzone rozporządzeniem Ministra Zdrowia z dnia 13 marca 2020 r. $^{25}$, kolejne rozporządzeniem tego samego organu administracji publicznej z dnia 20 marca $^{26}$. Następne ograniczenia były wprowadzone rozporządzeniami Rady Ministrów ${ }^{27}$. Ograniczenia były modyfikowane przez kolejne miesiące, by po ponad roku trwania epidemii, w maju 2021 r., przyjąć postać zezwolenia na zgromadzenia organizowane $\mathrm{w}$ ramach działalności kościołów i innych związków

24 Takie stanowisko wywołało krytykę wielu środowisk, w tym uzasadnioną krytykę autorytetów prawniczych. Niewprowadzenie stanu nadzwyczajnego i oceniane negatywnie próby zarządzania epidemią, w oparciu o przygotowywane naprędce, protetyczne, zmieniane ad hoc akty prawne, doprowadziło do chaosu prawnego, naruszyło szereg praw obywatelskich i w swej istocie stanowiło obchodzenie Konstytucji RP.

25 Powołane w przyp. 22 rozporządzenie Ministra Zdrowia z dnia 13 marca $2020 \mathrm{r}$. w sprawie ogłoszenia na obszarze Rzeczypospolitej Polskiej stanu zagrożenia epidemicznego.

26 Powołane w przyp. 23 rozporządzenie Ministra Zdrowia z dnia 20 marca $2020 \mathrm{r}$. w sprawie ogłoszenia na obszarze Rzeczypospolitej Polskiej stanu epidemii.

27 Pierwszym było rozporządzenie Rady Ministrów z dnia 31 marca 2020 r. w sprawie ustanowienia określonych ograniczeń, nakazów i zakazów w związku z wystąpieniem stanu epidemii, Dz. U. z 2020 r., poz. 566. Należy przypomnieć, że rozporządzenie zostało wydane na podstawie art. 46a i 46b u.z.z.z.ch.z., dodanych do niej w wyniku przygotowanej naprędce nowelizacji, które weszło w życie od 31 marca, a uchylone zostało 10 kwietnia 2020 r. Do „ograniczenia uprawiania kultu religijnego" wprowadzonego przedmiotowym rozporządzeniem krytycznie odniósł się już 3 kwietnia 2020 r. Rzecznik Praw Obywatelskich; zob. Pismo Rzecznika Praw Obywatelskich z dnia 3 kwietnia 2020 r. do Prezesa Rady Ministrów, VII.565.3.2020.ST/MM, https:/www.rpo.gov.pl/sites/default/files/Pismo\%20do\%20Prezesa\%20Rady\%20Ministr\%C3\%B3w.\%203.04.2020.pdf [dostęp: 13.05.2021]. 
„pod warunkiem, że w przypadku gdy zgromadzenie odbywa się w budynkach i innych obiektach kultu religijnego, znajduje się w nich, przy zachowaniu odległości nie mniejszej niż $1,5 \mathrm{~m}$, nie więcej uczestników niż 1 osoba na $15 \mathrm{~m} 2$ powierzchni, oprócz osób sprawujących kult religijny lub osób dokonujących pochowania, lub osób zatrudnionych przez zakład lub dom pogrzebowy w przypadku pogrzebu, oraz że uczestnicy realizują nakaz zakrywania ust i nosa [...] z wyłączeniem osób sprawujących kult religijny; na zewnątrz, uczestnicy przebywają w odległości nie mniejszej niż 1,5 m od siebie” i z zastrzeżeniem, że ,przed wejściem do [...] obiektów kultu religijnego informuje się o limicie osób [...] oraz podejmuje środki zapewniające jego przestrzeganie" ${ }^{28}$. Przedmiotowe ograniczenia, na przestrzeni roku, były normowane kilkudziesięcioma kolejnymi rozporządzeniami Rady Ministrów „,w sprawie ustanowienia określonych ograniczeń, nakazów i zakazów w związku z wystąpieniem stanu epidemii" lub ich zmianami (na początku maja 2021 r. było ich w sumie 66) ${ }^{29}$. Wszystkie regulacje budziły dyskusje dotyczące ich zgodności z Konstytucją RP i ustawami, zarówno z punktu widzenia formy aktu prawnego, którym zostały wprowadzone, jak i dopuszczalności samej ingerencji w funkcjonowanie Kościoła Katolickiego, która w rzeczywistości stanowiła ingerencję W wolność religii ${ }^{30}$.

Choć wiążące rozstrzygnięcia dotyczące zgodności wprowadzanych ograniczeń z przepisami konstytucyjnymi i ustawowymi należą do władzy sądowniczej, to warto przypomnieć, że analizując to zagadnienie należy je rozpatrywać na tle przepisów regulujących zarówno relacje pomiędzy państwem a Kościołem Katolickim, jak warunki dopuszczalności ograniczeń wolności i praw człowieka, jakimi są wolność religii i wolność słowa.

W kontekście oceny zgodności wprowadzanych ograniczeń z przepisami regulującymi relacje pomiędzy państwem a Kościołem Katolickim niektórzy krytycy wprowadzanych restrykcji zarzucali, że stanowią one nieuprawnioną ingerencję w autonomię tej wspólnoty religijnej. Zgodnie

28 § 26 ust. 9-11 rozporządzenia Rady Ministrów z dnia 6 maja 2021 r. w sprawie ustanowienia określonych ograniczeń, nakazów i zakazów w związku z wystąpieniem stanu epidemii, Dz. U. z 2021 r., poz. 861.

29 Autorka świadomie rezygnuje z przywoływania wszystkich kolejnych regulacji, ponieważ nie zmieniają one istoty i charakteru ograniczeń.

30 Rozważania na temat legalności wprowadzanych ograniczeń: Maroń 2021, 37-47. 
z Konstytucją RP stosunki między państwem a Kościołem Katolickim są kształtowane na zasadach poszanowania ich autonomii oraz wzajemnej niezależności każdego w swoim zakresie, a także współdziałania dla dobra człowieka i dobra wspólnego. Natomiast władze publiczne są zobowiązane do zapewnienia swobody wyrażania przekonań religijnych w życiu publicznym (art. 25 ust. 2-3 Konstytucji RP) ${ }^{31}$. Relacje te zostały uregulowane również w umowie międzynarodowej, jaką jest Konkordat między Stolicą Apostolską a Rzecząpospolitą Polską ${ }^{32}$. Zgodnie z jego postanowieniami państwo zapewnia Kościołowi Katolickiemu swobodne i publiczne pełnienie jego misji, w tym wykonywanie jurysdykcji, zarządzanie i administrowanie jego sprawami na podstawie prawa kanonicznego (art. 5). Na rzecz tezy o bezpodstawnej ingerencji w autonomię Kościoła przywoływane były również przepisy ustawowe regulujące stosunek państwa do Kościoła Katolickiego, zgodnie z którymi „Kościół rządzi się w swych sprawach własnym prawem, swobodnie wykonuje władzę duchowną i jurysdykcyjną oraz zarządza swoimi sprawami”, a „organizowanie kultu publicznego i jego sprawowanie podlega władzy kościelnej" "33. Czy zatem - w świetle przytoczonych zarzutów - wprowadzane ograniczenia były naruszeniem przepisów regulujących relacje między państwem a Kościołem Katolickim, poprzez ingerencję w autonomię Kościoła - a więc poprzez ingerencję w zakres działania i spraw, należących do przestrzeni autonomii i niezależności Kościoła Katolickiego, mający swój wyraz m.in. w przedmiocie regulacji prawa wewnętrznego (kościelnego) $)^{34}$ - i z tego powodu stanowią naruszenie prawa? Udzielając odpowiedzi na to pytanie należy podkreślić, że choć restrykcje motywowane epidemią doprowadziły do zmiany funkcjonowania Kościoła Katolickiego i stanowiły ograniczenie wolności uzewnętrzniania religii, to jednak nie były ingerencją w wykonywanie władzy duchownej i jurysdykcyjnej oraz zarządzanie sprawami Kościoła. Nie oznaczały

31 Szerzej: Stanisz 2020, 36-39; Uruszczak, Góralski, Krukowski 2020, 124-134.

32 Konkordat między Stolicą Apostolską a Rzecząpospolitą Polską podpisany dnia 28 lipca 1993 r., Dz. U. z 1998 r. Nr 51, poz. 318.

33 Art. 2 i art. 15 ust. 1 ustawy z dnia 17 maja 1989 r. o stosunku Państwa do Kościoła Katolickiego w Rzeczypospolitej Polskiej, tekst jedn. Dz. U. z 2019 r., poz. 1347, dalej: u.s.p.k.k.

34 Por. Borecki 2012, 7. 
też organizowania kultu publicznego przez państwo, zatem nie stanowiły ingerencji w autonomię Kościoła. Walka z epidemią i ochrona zdrowia publicznego należy do zadań państwa, a podejmowane w ich ramach działania - przynajmniej co do zasady - nie mogą być traktowane jako ingerencja w autonomię Kościoła. Warto pamiętać, że podstawy materialnoprawne do działań podjętych w tym zakresie przez państwo dają wprost regulacje zawarte w przywołanych wyżej aktach prawnych, które dopuszczają w ściśle określonych okolicznościach ingerencję w funkcjonowanie Kościoła i w wolność religii. Po pierwsze art. 53 ust. 5 Konstytucji RP - o czym była mowa wcześniej - dopuszcza ograniczenia wolności uzewnętrzniania religii, a więc m.in. publicznych praktyk religijnych, gdy jest to konieczne do ochrony zdrowia. Po drugie, zgodnie $\mathrm{z}$ art. 8 ust. 2 Konkordatu, choć organizowanie kultu publicznego należy do władzy kościelnej zgodnie z przepisami prawa kanonicznego, to działania takie nie mogą naruszać przepisów prawa polskiego. Państwo niewątpliwie ma prawo oczekiwać współdziałania Kościoła w zwalczaniu epidemii. Wreszcie warto przypomnieć, że przepisy Konkordatu, pomimo przyjętej zasady nienaruszalności miejsc kultu i cmentarzy oraz zasady współdziałania państwa i Kościoła, dopuszczają nawet, by władza publiczna podejmowała niezbędne działania w tych miejscach, także bez uprzedniego powiadamiania władzy kościelnej, jeśli jest to konieczne m.in. dla ochrony życia i zdrowia (art. 8 ust. 5) ${ }^{35}$. Ten przepis stanowi więc przykład wyłączenia, na zasadzie wyjątku, przyjętej we wzajemnych relacjach państwa i Kościoła zasady współdziałania.

Zatem podjęte przez państwo działania mające zapobiegać rozprzestrzenianiu się epidemii, które w praktyce stanowiły ingerencję w wolność religii i ograniczyły funkcjonowanie Kościoła, były dopuszczalne z perspektywy zarówno przedmiotu regulacji (ochrona życia i zdrowia), jak i przepisów regulujących stosunki państwo-Kościół Katolicki. Jednak nie jest to jedyna i wystarczająca przesłanka, by wprowadzone ograniczenia uznać za zgodne z prawem. By ograniczenia posiadały taki status, powinny być również „konieczne w demokratycznym państwie prawa” i ustanowione w ustawie.

35 J. Krukowski przesłankę „niezbędności działania” wyjaśnia jako ,naglącą konieczność” (Krukowski 2005, 132). 
Nie sposób obiektywnie rozstrzygnąć, czy wprowadzona ingerencja w wolność religii była konieczna. Prawodawca nie ujawnił, co decydowało o wyborze konkretnych ograniczeń. Ogólnie rzecz ujmując można jednak stwierdzić, że ograniczenia dotyczące wszystkich obszarów życia społecznego wprowadzane były arbitralnie, chaotycznie, bez ich uzasadnienia wiarygodnymi danymi. Swoich działań administracja publiczna nie opierała na analizie danych empirycznych, bo takimi nie dysponowała. Deklarowano, że konieczność wprowadzanych ograniczeń była konsultowana $\mathrm{z}$ ekspertami, zatem w aktualnym stanie wiedzy nie ma podstaw, by podważać ich zasadność. Należy podzielić stanowisko, że „W sprawach dotyczących ochrony życia i zdrowia dużo większy zarzut można by postawić władzy, gdyby poziom obostrzeń okazał się zbyt niski wobec poziomu zagrożenia, niż gdyby miał być za wysoki" ${ }^{36}$. Należy także jednak dodać, że wykazanie zbyt wysokiego poziomu obostrzeń stanowiłoby przesłankę stwierdzenia bezprawności ingerencji.

Ostatnią kwestią jest dochowanie prawnej formy wprowadzanych ograniczeń. Wolność uzewnętrzniania religii i realizowana w jej ramach wolność wypowiedzi mogą być ograniczane jedynie w drodze ustawy, natomiast omówione ograniczenia były wprowadzane rozporządzeniami, co jednoznacznie i ostatecznie przesądza ocenę zgodności z prawem wprowadzanych ograniczeń - zostały one wprowadzone z naruszeniem prawa. Fakt, że społeczeństwo im się podporządkowało, należy tłumaczyć postawą odpowiedzialności za siebie i innych, za swoje i innych zdrowie i życie. Był to rodzaj obywatelskiego samoograniczenia się społeczeństwa. Nie zmienia to jednak formalnej oceny legalności wprowadzanych ograniczeń. Mając zatem świadomość, że z formalnego punktu widzenia stanowiły one naruszenie zasad określonych w Ustawie zasadniczej, warto zastanowić się, jakie były praktyczne konsekwencje ich wprowadzenia dla wolności słowa realizowanej w ramach wolności religii.

36 Krzewicki 2020, 89. 


\section{PRAKTYCZNE KONSEKWENCJE WPROWADZANYCH} OGRANICZEŃ DLA WOLNOŚCI SŁOWA REALIZOWANEJ

W RAMACH WOLNOŚCI RELIGII

Przeprowadzone dotychczas analizy wykazały, że wprowadzone ze względu na epidemię ograniczenia dotyczące funkcjonowania Kościoła Katolickiego stanowiły realną ingerencję w wolność uzewnętrzniania religii. Ponieważ $\mathrm{w}$ tej przestrzeni - uzewnętrzniania religii - realizowana jest również wolność słowa, poddawana była ona tym samym ograniczeniom, które dotyczyły wolności religii.

Wolność słowa jest wolnością uzewnętrzniania, a więc wprowadzania do obiegu publicznego, określonych treści, a także wolnością ich pozyskiwania i rozpowszechniania. Na wolność słowa w ramach wolności religii można spojrzeć z dwóch zasadniczych perspektyw - z perspektywy nadawcy treści i z perspektywy ich odbiorcy. Nadawcą treści w omawianej sytuacji jest Kościół Katolicki jako instytucja działająca przez swoich przedstawicieli w ramach nauczania i sprawowania praktyk religijnych. Odbiorcą będzie każdy w ramach wspólnoty wiernych. Ograniczenia funkcjonowania Kościoła Katolickiego wprowadzone ze względu na epidemię SARS-CoV-2 wywoływały skutki w obu wspomnianych wyżej perspektywach i stanowiły ingerencję zarówno w uprawnienia nadawcy, jak i odbiorcy treści. Ograniczenie liczby osób, które mogły uczestniczyć w obrzędach religijnych stanowiło jednocześnie ograniczenie wolności słowa, zarówno nadawcy, jak i odbiorcy. Z perspektywy uprawnień nadawcy treści wprowadzone regulacje ograniczyły znacząco możliwość dotarcia w sposób bezpośredni do odbiorców, a do części z nich dotarcie bezpośrednie uniemożliwiło. W praktyce uniemożliwiło to więc również wprowadzanie treści do obiegu publicznego $\mathrm{i}$ ich rozpowszechnianie $\mathrm{w}$ podstawowy przyjęty przez instytucje Kościoła Katolickiego sposób, a więc bez pośrednictwa środków komunikacji. Uwaga ta dotyczy zarówno oficjalnych przekazów przedstawicieli hierarchii kościelnej, jak i przekazów innych duchownych w trakcie sprawowania obrzędów religijnych. Z kolei odbiorcom, którzy nie mogli uczestniczyć w obrzędach religijnych, wprowadzone ograniczenia uniemożliwiły pozyskiwanie treści w ramach bezpośredniego uczestniczenia w obrzędach religijnych. Wprowadzone ograniczenia stanowiły ingerencję nie tylko w wolność religii, ale również w wolność 
słowa - rozumianą jako wolność wprowadzania, rozpowszechniania i pozyskiwania określonych treści, w tym wypadku związanych z publiczną zbiorową aktywnością religijną - wszystkich członków wspólnoty Kościoła Katolickiego. Ograniczenie wolności słowa, w ramach wolności religii, jest więc także formą ograniczania ,wolności uzewnętrzniania [...] wspólnie z innymi, publicznie [...] swego wyznania lub przekonań przez uprawianie kultu, nauczanie, praktykowanie i czynności rytualne". Obie wolności są ze sobą w tym konkretnym przypadku powiązane.

Wprowadzone ograniczenia dotyczące wolności uzewnętrzniania religii miały wpływ również na szczególny aspekt wolności słowa, jakim jest wolność prasy, w tym przypadku katolickiej ${ }^{37}$. Środki społecznego przekazu tworzone przez Kościół Katolicki są jednym ze sposobów realizacji jego funkcji, zagwarantowanym przepisami aktów prawnych regulujących jego relacje z państwem. Zgodnie z przepisami Konkordatu Kościół „ma prawo swobodnego drukowania, wydawania i rozpowszechniania wszelkich publikacji związanych z jego posłannictwem” oraz ,prawo do posiadania i używania własnych środków społecznego przekazu [...] na zasadach określonych w prawie polskim" (art. 20). Kwestię tę regulują również przepisy ustawowe. Prawo Kościoła Katolickiego do wydawania prasy, z zachowaniem obowiązujących w tym zakresie przepisów prawa oraz prawo jej kolportażu, w ramach własnej sieci kolportażu lub z wykorzystaniem innych sieci, służy „zapewnieniu warunków rozwoju kultury chrześcijańskiej w Polsce" (art. 46-47 u.s.p.k.k.) oraz realizacji funkcji Kościoła Katolickiego (art. 25 u.g.w.s.). Prasa w polskim systemie prawnym jest pojęciem zdefiniowanym ustawowo (art. 7 ust. 2 pkt 1 pr. pras.), a w świetle przyjętej definicji można stwierdzić, że w ramach działalności prasowej wyróżniamy prasową działalność wydawniczą i prasową działalność dziennikarską. O ile w ramach ograniczania wolności religii zasadniczo nie dochodzi do ograniczania wolności prasowej działalności dziennikarskiej, to bez wątpienia znacząco została ograniczona wolność prasowej działalności wydawniczej w przestrzeni rozpowszechniania drukowanej prasy katolickiej. Wynika to z faktu, że dla części sztandarowych tytułów prasy katolickiej,

37 Prawo Kościoła Katolickiego do posiadania własnych środków przekazu jest przejawem jego autonomii i formą rozwijania kultury. Zob. Uruszczak, Góralski, Krukowski 2020, 168-172; Krukowski 2005, 185-188; Mezglewski, Misztal, Stanisz 2008, 206-207. 
sieć parafii stanowi podstawową i zasadniczą sieć kolportażu i dystrybu$\mathrm{cji}^{38}$. W sytuacji drastycznego ograniczenia liczby osób mogących brać udział w obrzędach religijnych sprawowanych w świątyniach, drastycznie zostało ograniczone rozpowszechnianie drukowanej prasy katolickiej. Tezę tę potwierdzają doniesienia podmiotów badających sprzedaż, dystrybucję, a tym samym rozpowszechnianie prasy podczas trwającej epide$\mathrm{mii}^{39}$. „Ograniczenia spowodowane koronawirusem stanowią podwójne wyzwanie dla popularnych polskich publikacji katolickich. Zamknięcie wielu punktów kolportażu oraz nałożone przez rząd ograniczenia związane z gromadzeniem się w świątyniach, spowodowały utrudnienia w sprzedaży i promocji" ${ }^{40}$. Należy dodać, że ograniczenia w praktyce, w realny i konkretny sposób ingerowały w wolność prasy katolickiej, a tym samym w wolność słowa realizowaną w ramach wolności religii.

38 Np. „Gość Niedzielny” przez sieć parafii realizuje 78\% sprzedaży - tak: Katolicka Agencja Informacyjna. 2019. „Redaktor naczelny GN: Sytuacja prasy w Polsce i w Europie jest coraz trudniejsza", https://www.ekai.pl/redaktor-naczelny-gn-sytuacja-prasy-w-polsce-i-w-europie-jest-coraz-trudniejsza/ [dostęp: 13.05.2021].

39 Należy zauważyć, że skutki epidemii, choć w różnym stopniu, dotknęły cały segment prasy. Por. Łysoń 2020, 78-86.

40 Erling, Barbara. „Polish media under the pandemic: fears over financial future and political interference", Notes From Poland, https://notesfrompoland.com/2020/04/28/as-media-revenues-plummet-during-pandemic-fears-that-political-influence-could-increase/ [dostęp: 13.05.2021]. Już 28 kwietnia 2020 r. B. Erling informowała: „Gość Niedzielny, katolickie pismo, które jest najlepiej sprzedającym się tygodnikiem w Polsce, odnotował gwałtowny spadek sprzedaży w związku z zamknięciem parafian w swoich domach. «W marcu ograniczyliśmy nakład o 2/3 i w takiej ilości wydaliśmy kolejne trzy numery aż do numeru wielkanocnego, które trafią wyłącznie dla dystrybucji pozakościelnej» mówi ks. Adam Pawlaszczyk, redaktor naczelny. Przed kryzysem magazyn osiągał średnio ok. 100 tys. egzemplarzy tygodniowej sprzedaży. «Nie mamy danych marcowych, ale jakikolwiek spadek będzie bolesny» powiedział Wirtualnym Mediom Piotr Sudoł, szef działu promocji. [...] Ks. Artur Stopka w poście opublikowanym na stronie internetowej Polskiego Stowarzyszenia Dziennikarzy napisał, że katoliccy wydawcy nie mają opracowanej żadnej strategii działania w przypadku nagłego załamania się dystrybucji w Kościołach. «Jeśli wydawcy cotygodniowych czasopism katolickich koncentrują się wyłącznie na przetrwaniu okresu pandemii i nie wykorzystują tego czasu na przygotowanie poważnych przemian, może się okazać, że nastąpi stopniowy rozpad tego systemu. A nowego nie będzie» ostrzega Stopka”. Zob. także: Gospodarek 2021, 155-177. 


\section{ZAKOŃCZENIE}

Celem niniejszego opracowania było znalezienie odpowiedzi na pytanie, czy wprowadzane w Polsce ograniczenia, uzasadniane walką z epidemią SARS-CoV-2, a w praktyce modyfikujące funkcjonowanie Kościoła Katolickiego, wpływają na wolność słowa realizowaną w ramach wolności religii. Przeprowadzone analizy doprowadziły do wniosku, że ograniczanie wolności religii w jej wymiarze zewnętrznym jest także ograniczaniem wolności słowa realizowanej w ramach wolności religii. Obie wolności są wyznaczone przez ustanowione w powszechnie obowiązujących przepisach prawa ramy normatywne. W praktyce ograniczenie wolności religii przez działania administracji publicznej spowodowało również ograniczenie wolności słowa, zarówno w przestrzeni wprowadzania i rozpowszechniania treści w sposób bezpośredni przez duchownych, jak i w przestrzeni pozyskiwania tych treści w sposób bezpośredni przez wiernych w ramach publicznych praktyk religijnych. Działania podjęte przez administrację publiczną skutkowały również ograniczeniem wolności słowa w jej szczególnym przypadku, jakim jest wolność prasy, a dotyczyły drukowanej prasy katolickiej. Wprowadzone ograniczenia stanowiły ingerencję w wolność prasowej działalności wydawniczej, w przestrzeni wolności rozpowszechniania prasy.

Wydaje się, że w obliczu zagrożeń związanych z epidemią SARS-CoV-2 ograniczanie niektórych praw i wolności człowieka w celu ochrony życia i zdrowia jest uzasadnione, jednak działania takie powinny być podejmowane $\mathrm{z}$ respektowaniem wymogów prawa. Tymczasem, choć wolność religii i wolność słowa mogą być w sposób legalny ograniczane w ściśle określonych sytuacjach, to analiza ograniczeń wprowadzonych w ramach walki z epidemią SARS-CoV-2 prowadzi do wniosku, że nie posiadają one przymiotu konstytucyjności i legalności. Sposób wprowadzanych ograniczeń przez administrację publiczną powinien budzić uzasadniony sprzeciw - działania takie prowadzą do erozji prawa i niszczą jego autorytet, są łamaniem elementarnych praw i wolności człowieka oraz świadczą o arogancji w stosunku do podmiotów administrowanych. Dodatkowo naznaczają negatywnie relacje między państwem a Kościołem Katolickim, czyli w praktyce mogą również destabilizować stosunki międzynarodowe. Takich „standardów” sprawowania administracji publicznej nie 
może usprawiedliwiać epidemia i nie jest możliwe ich zaakceptowanie w demokratycznym państwie prawa.

\section{BIBLIOGRAFIA}

Borecki, Paweł. 2012. „Autonomia Kościołów i innych związków wyznaniowych we współczesnym prawie polskim". Przeglad Prawa Publicznego 4: 7-21.

Del Castillo, Fides A., Hazel T. Biana, Jeremiah Joven B. Joaquin. 2020. "ChurchInAction: the role of religious interventions in times of COVID-19". Journal of Public Health 3 (43): 633-634.

Falski, Jacek. 2015. „Symbolika i przekonania religijne w miejscu pracy (na tle wyroku Europejskiego Trybunału Praw Człowieka w sprawie Eweida i inni v. Wielka Brytania)". Państwo i Prawo 8: 77-90.

Florczak-Wątor, Monika. 2020. „Niekonstytucyjność ograniczeń praw i wolności jednostki wprowadzonych w związku z epidemią COVID-19 jako przesłanka odpowiedzialności odszkodowawczej państwa”. Państwo i Prawo 12: 5-22.

Gardocki, Lech. 1993. „Europejskie standardy wolności wypowiedzi a polskie prawo karne". Państwo i Prawo 3: 11-27.

Garlicki, Leszek, Krzysztof Wojtyczek. 2016. „Art. 31”. W: Konstytucja Rzeczypospolitej Polskiej. Komentarz. T. II, wyd. II, red. Leszek Garlicki, Marek Zubik. Warszawa: Wydawnictwo Sejmowe.

Garlicki, Leszek. 2001. „Przesłanki ograniczania konstytucyjnych praw i wolności (na tle orzecznictwa Trybunału Konstytucyjnego)". Państwo i Prawo 10: $5-24$.

Gądecki, Stanisław. 2021. „Duszpasterstwo po pandemii”, Katolicka Agencja Informacyjna, https://www.ekai.pl/abp-stanislaw-gadecki-duszpasterstwo-po-pandemii/.

Gospodarek, Dawid. 2021. „Media katolickie”. W: Kościót w Polsce. Raport, red. Marcin Przeciszewski, Rafał Łączny. Warszawa: Katolicka Agencja Informacyjna.

Jaskuła, Lidia Katarzyna. 2008. Prawo do dobrego imienia a wolność prasy. Warszawa: Wydawnictwo C.H. Beck.

Kamiński, Ireneusz Cezary. 2002. Swoboda wypowiedzi w orzeczeniach Europejskiego Trybunału Praw Człowieka w Strasburgu. Kraków: Zakamycze.

Kamiński, Ireneusz Cezary. 2008. „Media w europejskiej konwencji o ochronie praw człowieka i podstawowych wartości”. W: Prawo mediów, red. Janusz Barta, Ryszard Markiewicz, Andrzej Matlak, 33-81. Warszawa: Wydawnictwo Prawnicze LexisNexis. 
Kamiński, Ireneusz Cezary. 2010. Ograniczenia swobody wypowiedzi dopuszczalne w Europejskiej Konwencji Praw Człowieka. Analiza krytyczna. Warszawa: Wolters Kluwer Polska.

Kamiński, Ireneusz Cezary. 2012. „Wolność religijna a jednostka”. W: Prawne granice sumienia $i$ wyznania, red. Roman Wieruszewski, Mirosław Wyrzykowski, Lena Kondratiewa-Bryzik. Warszawa: Wolters Kluwer Polska.

Krukowski, Józef. 2005. Polskie prawo wyznaniowe. Warszawa: Wydawnictwo Prawnicze LexisNexis.

Krzewicki, Jarosław. 2020. „Relacje Kościół-Państwo w Polsce wobec Covid-19”. Kościót i Prawo 9: 83-100.

Łysoń, Tomasz. 2020. „Zmieniający się rynek polskich tygodników opinii na początku pandemii COVID-19”. Com.press 3 (2): 68-87.

Maroń, Grzegorz. 2021. „Polskie prawodawstwo ograniczające wolność religijną w okresie pandemii koronawirusa SARS-CoV-2 a standardy państwa prawa wybrane zagadnienia”. Przeglad Prawa Publicznego 1: 33-49.

Mezglewski, Artur, Henryk Misztal, Piotr Stanisz. 2008. Prawo wyznaniowe. Warszawa: Wydawnictwo C.H. Beck.

Misztal, Henryk. 1996. Polskie prawo wyznaniowe. Lublin: Redakcja Wydawnictw Katolickiego Uniwersytetu Lubelskiego.

Nowicki, Marek Antoni. 2017. Wokót Konwencji Europejskiej. Komentarz do Europejskiej Konwencji Praw Człowieka. Warszawa: Wolters Kluwer Polska.

Nowińska, Ewa. 2007. Wolność wypowiedzi prasowej. Warszawa - Kraków: Wolters Kluwer Polska.

Sobczak, Jacek. 2000. Prawo prasowe. Podręcznik akademicki. Warszawa: Oficyna Prawnicza Muza.

Sobczak, Jacek. 2008. Prawo prasowe. Komentarz. Warszawa: Wolters Kluwer Polska.

Sobczak, Maria. 2008. „Wolność sumienia i wyznania, jej gwarancje w systemie prawnym Rady Europy oraz w orzecznictwie Europejskiego Trybunału Praw Człowieka w Strasburgu". Ius Novum 3: 87-116.

Stanisz, Piotr. 2020. Religion and Law in Poland. Alphen aan den Rijn: Wolters Kluwer.

Szostkiewicz, Adam. 2020. „Jak ograniczenia pandemiczne, to też dla Kościoła”. Polityka, 12 października 2020 r., https://www.polityka.pl/tygodnikpolityka/ kraj/1974684,1,jak-ograniczenia-pandemiczne-to-tez-dla-kosciola.read

Uruszczak, Wacław, Wojciech Góralski, Józef Krukowski. 2020. Concordats between the Holy See and Poland. History and Present. Lublin: Towarzystwo Naukowe KUL. 
Wiśniewski, Adam. 2013. „O symbolach religijnych w orzecznictwie strasburskim”. Gdańskie Studia Prawnicze 29: 261-277.

Wółkowska, Magdalena. 2013. „Prawa kulturalne w Europejskiej Konwencji Praw Człowieka. Analiza w oparciu o orzecznictwo Europejskiego Trybunału Praw Człowieka w Strasburgu”. Studia Iuridica Toruniensia 2: 241-260. 